\title{
Flexible OPV modules for highly efficient indoor applications
}

\author{
Mari Ylikunnari ${ }^{1}$, Marja Välimäki ${ }^{1}$, Kaisa-Leena Väisänen ${ }^{1}$, Thomas M. Kraft ${ }^{1}$, Rafal \\ Sliz $^{2}$, Gianni Corso ${ }^{3}$, Marja Vilkman ${ }^{4}$ \\ ${ }^{1}$ VTT Technical Research Centre of Finland, Kaitoväylä 1, FI-90571 Oulu, Finland \\ ${ }^{2}$ University of Oulu, Optoelectronics and measurement techniques laboratory, 90014 University of \\ Oulu, Finland \\ ${ }^{3}$ Eni S.p.A, Renewable Energy \& Environmental R\&D, Via Fauser 4, 28100 Novara, Italy \\ ${ }^{4}$ VTT Technical Research Centre of Finland, Tietotie 3, FI-02150 Espoo, Finland \\ E-mail: mari.ylikunnari@vtt.fi
}

Received xxxxxx

Accepted for publication $\mathrm{xxxxx}$

Published xxxxxx

\begin{abstract}
The comparison of solution processed organic photovoltaics (OPVs) with two roll-to-roll coated electron transport layers (ETL), as well as printed grid or solid back electrodes provides insight into the future of $\mathrm{R} 2 \mathrm{R}$ fabricated architectures. The variation in performance of the $\mathrm{R} 2 \mathrm{R}$ slot-die coated zinc oxide $(\mathrm{ZnO})$ versus the tin oxide $\left(\mathrm{SnO}_{2}\right)$, showed a clear dependence on the spectrum of the illumination source. It was found that under indoor light conditions (200 - 1000 lux LED and fluorescent sources) the $\mathrm{SnO}_{2}$ outperformed the $\mathrm{ZnO}$ with highest efficiencies near $13 \%$ and $10 \%$ respectively. This is in contrast to results obtained under 1 sun (AM 1.5) in which the cells fabricated with a ZnO ETL had a higher power conversion efficiency than those prepared with $\mathrm{SnO}_{2}$. The results also confirm the significance of the layout of the printed silver back contact; in which cells with the grid structure outperformed those with full coverage by approximately $35 \%$ for $\mathrm{ZnO}$ and just under $10 \%$ for $\mathrm{SnO}_{2}$ (all light conditions). The combination of a R2R coating and S2S printing process to prepare modules with 8 cells in series (PET/ITO/SnO $2 / \mathrm{PV} 2001: \mathrm{PCBM} / \mathrm{PEDOT}: \mathrm{PSS} /$ silver grid) resulted in a PCE of $13.4 \%$ under indoor office light conditions.
\end{abstract}

Keywords: Organic photovoltaics, indoor light, R2R, S2S, Polymer solar cells, Solution-processed

\section{Introduction}

Light sources that are accessible to everyone, and everywhere are lacking full-scale utilization. Solar energy technologies are able to provide solutions for Internet-of-Things (IoT) based applications such as smart gadgets, as well as intergrating them into buildings for the purpose of harvesting energy in the form of smart walls/surfaces. [1] [2] None of the existing thin-film technologies have yet reached the efficiency levels and lifetimes of traditional silicon PV systems, but they have the huge potential to spread into a wide range of end-use areas due to the lightweight and flexibility. [3] In addition, the capability of using well-established and widely used roll-to-roll (R2R) mass-production methods under ambient atmosphere, and utilizing materials that are toxic-free is an advantage obtained with organic photovoltaics (OPV). [4] [5] 
The ability to obtain high power conversion efficiencies (PCE) under different lighting conditions is one of the main benefits of using OPVs. [1] Until now, over 17\% record efficiency for OPV cells under solar irradiation has been obtained. [6] [7] Polymer-based donor-materials has reached PCE of over $16 \%$ with ternary bulk-heterojuction (BHJ) structure and also by using non-fullerence ternary BHJ structure, respectively. [8] [9] So far, the highest $28.1 \%$ efficiency under indoor light for OPV has been obtained with small molecule-based cells. Likewise, the efficiencies obtained with polymer-based cells have reached $26.1 \%$ with a ternary structure and $18.72 \%$ with a binary structure. [10] [11]

Until now, indoor characterization of polymer-based OPV have covered poly(3-hexylthiophene) (P3HT), poly[(2,5-bis(2hexyldecyloxy)phenylene)-alt-(5,6-difluoro-4,7-di(thiophen-2-yl)benzo[c][1,2,5]thiadiazole)] (PPDT2FBT), thieno[3,4b] thiophene-alt-benzodithiophene copolymer (PTB7), poly([2,6'-4,8-di(5-ethylhexylthienyl)benzo [1,2-b,3,3-b]dithiophene]3fluoro-2[(2-ethylhexyl)carbonyl]thieno [3,4-b]thiophenediyl) (PTB7-Th), poly[N-9"-heptadecanyl-2,7-carbazole-alt-5,5$\left(4^{\prime}, 7^{\prime}\right.$-di-2-thienyl-2',1',3'-benzothiadiazole)] (PCDTBT). [1] [11] [12] [13] [14] [15] [16] [17] [18] There have however been few studies that have dealt with processing on PET substrate instead of glass, and fabrication of the actual modules. [17] [19] Among other donor-polymers, the solution processable PV2000 with [6,6]-phenyl C61 butyric acid methyl ester (PCBM) has shown PCE of $4.3 \%$ and $8.0 \%$ with fully ink-jet printed and spin-coated devices under solar irradiation, respectively. [20] [21] [22] Quite recently, the PCE of PV2000-based material have reached $7.56 \%$ in solution-processed modules prepared in ambient conditions with the possibility to operate in a wide range of film thickness. [23]

From solution processable materials, polyethylenimine (PEIE), poly [(9,9-bis(3'-(N,N-dimethylamino)propyl)-2,7-fluorene)alt-2,7-(9,9-dioctylfluorene)] $(\mathrm{PFN})$, titanium oxide $\left(\mathrm{TiO}_{\mathrm{x}}\right)$ and zinc oxide $(\mathrm{ZnO})$ have been used as electron transport layer (ETL) under indoor light conditions. [1] [12] [14] [15] [17] However, $\mathrm{ZnO}$ is dependent on light soaking. Thus, it might not be the most optimal ETL material for low light intensities. [24] Only a few studies have addressed the use of solution processed hole transporting and hole conctact materials for indoor OPV by using poly(3,4-ethylenedioxythiophene) polystyrene sulfonate (PEDOT:PSS) with silver or carbon paste. [25]

Currently, studies to replace the $\mathrm{ZnO}$ with tin oxide $\left(\mathrm{SnO}_{2}\right)$ for indoor light conditions to avoid additional light soaking have not been reported. Furthermore, research related to the indoor evaluation of PV2000-based cells appear to be nonexistent, eventhough the possibility of obtaining higher thickness could prevent leakage current, thus being more suitable for the cells to operate under indoor light. [23] [15]

Herein, OPVs were prepared by R2R slot-die coating and screen printing on a flexible plastic substrate indium tin oxide (ITO)PET/ZnO/PV2001:PCBM/PEDOT:PSS/silver and ITO-PET/SnO $2 /$ PV2001:PCBM/PEDOT:PSS/silver cells and modules see

Figure 1. Hole contact was printed as a full active area coverage and as a honeycomb-patterned grid. The use of honeycombstructured as hole conctact was considered to provide sufficient conductivity for low light intensities. Electrical characterization was performed using solar irration, fluorescent light and LED light at different intensities to verify the spectral compatibility indoor light sources as well as the absorption of thick PV2001:PCBM. $\mathrm{SnO}_{2}$ was preferred as an ETL instead of ZnO in indoor illumination together with a grid-patterned silver electrode. The average PCE in the modules were measured under fluorescent lamp (FL) with silver as a grid and $\mathrm{SnO}_{2}$ as the ETL.

\section{Methods}

In this study, a series of printed and coated organic solar cells were prepared comprising two electron transport material and two top electrode patterns. All cells were prosessed on patterned $(50 \Omega / \square)$ ITO coated PET foil with a thickness of $125 \mu \mathrm{m}$. ETL layer consisting of $\mathrm{ZnO}$ or $\mathrm{SnO}_{2}$ was slot-die coated with a roll-to-roll (R2R) pilot printing machine. $\mathrm{ZnO}$ (N-12) and $\mathrm{SnO}_{2}$ (N-31) nanoparticle solutions in alcohol were purchased separately from Avantama. A blend of PV2001 and PCBM with a mass ration of 1:1,5 in o-xylene was coated with the same technique. PV2001 was purchased from Raynergy Tek and PCBM from Nano-C. At this point, the substrate was cut into sheets and processed as sheet-to-sheet (S2S). Flat bed screen printing was used to print the hole transport layer (HTL) followed by the top electrode. The silver electrode had full coverage or a honeycomb pattern. HTL ink was PEDOT:PSS aqueous solution from Agfa (EL-P5015) and silver ink (XPVS-670) was purchased from PPG Industries. The devices were prepared in ambient environment and stored under nitrogen atmosphere in between processes. Finally, devices were encapsulated with 3M FTB3-50 barrier and pressure sensitive adhesive from Adhesives Research. 
Current-voltage (I-V) characterization was performed with an AM1.5G solar simulator (Atlas Solar Cell Test 1200) calibrated to $100 \mathrm{~mW} \mathrm{~cm}^{-2}$ using a calibrated Si-reference cell filtered with a KG5 filter. Indoor light measurements were carried out with two light sources, fluorescent light (Osram L18W/830) and LED light source (Nichia_3800K.int) in four illuminance level of 200, 400, 800 and 1000 lux. The lux level was adjusted by changing the distance between a light source and a sample holder. The illuminance value (lux) and light source spectrum togerher with light power spectrum $\left(\mathrm{mW} \mathrm{cm}^{-2}\right)$ were measured with Konica Minolta Illuminance Spectrophotometer CL-500A. Power spectrum was measured for both light sources at each lux level and the irradiance was calculated by integrating the individual spectrum. Totally 16 cells from each sample group were taken into AM1.5 measurements with an active area of $33 \mathrm{~mm}^{2}$ together with three modules of $\mathrm{ZnO}$ and $\mathrm{SnO}_{2}$ that had a grid structure in the top electrode and an active area of $1360 \mathrm{~mm}^{2}$. Modules comprised 8 serially connected cells. UV-vis and transmission spectrums were obtained using Varian Cary 5000 UV-vis-NIR spectrophotometer. The External Quantum Efficiency (EQE) measurements were performed using Automated Spectroradiometric Measurement System - Optronic Laboratories (USA). The spectral response of the solar cells was measured at a wavelength range of $300-900 \mathrm{~nm}$ with resolution $10 \mathrm{~nm}$. The light beam size was limited to $1 \mathrm{~mm}$ in diameter. To avoid sensor saturation, the light beam was chopped at a $167 \mathrm{~Hz}$ using an integrated lock-in amplifier. The sample cells were connected to the measurement system through the microprobe measurement system. After the measurements, the acquired data together with the QE energy conversion factor were used to calculate the EQE.

\section{Results and Discussion}

\section{Spectra of light sources}

Majority of OPV measurements are done under sunlight conditions such as AM1.5G measurements. However, the performance in these conditions does not reveal the behaviour of OPV in indoor lighting. [26] There are no standardized method to evaluate the indoor performance of solar cells but a large group consensus recommends FLs with an illuminance level between $200-$ 1000 lux, which corresponds to normal office light level. [27] Another widely used light source is LED that has spread into home and offices due to its low power consumption and much broader light spectrum than a FL as seen in Figure 2. A significant portion of these indoor light spectra are in the $600 \mathrm{~nm}$ range. A polymer that has good absoption spectral compatibility with indoor light sources is expected to be suitable for indoor applications. [16] The spectral match indicates that under indoor lighting the PCE of OPV is expected to be higher than under sunlight, because a cosiderable part of the sunlight spectrum is within the infrared region. The PCE is determined as the ratio of the solar cell maximum output power to the incident power on the solar cell from the lighting source. Since the spectrum of FL and LED light are different, irradiance ( $\left.\mathrm{mW} / \mathrm{cm}^{2} \mathrm{unit}\right) \mathrm{was}$ calculated by integrating the spectrum of individual lux level in order to determine the PCE (Supplementary Fig. 1). The same lux level of FL and LED resulted in different light intensity as seen in Table 1.

\section{Material properties}

Among various materials, metal oxides in particular have attracted a considerable attention as electron transport and hole blocking material in organic solar cells. $\mathrm{TiO}_{\mathrm{x}}$ and $\mathrm{ZnO}$ are mostly used due to their optical transparency, high electron mobility, good stability and processability. [28] [29] [30] In order to effectively utilize these metal oxide materials in the ETL, systems with a double ETL have been introduced where $\mathrm{ZnO}$ is combined with an additional layer of $\mathrm{SnO}_{2}, \mathrm{Al}$-doped $\mathrm{ZnO}$ or conjugated polymer to improve the interfacial properties and photovoltaic parameters. [31] [32] [33] [34] Recently, $\mathrm{SnO}_{2} \mathrm{has}_{\text {emerged as }}$ a promising ETL material to replace $\mathrm{ZnO}$ or $\mathrm{TiO}_{\mathrm{x}}$. $\mathrm{ZnO}$ has photocatalytical activity under UV light and both materials require a well-known light soaking to improve the performance level of organic solar cells. [35] [36] So far $\mathrm{SnO}_{2}$ has been widely used as an ETL for high performance perovskite solar cells. [37] [38] [39] [40] $\mathrm{SnO}_{2}$ is a light-soaking-free material due to its wider band gap as compared to $\mathrm{ZnO}$ and $\mathrm{SnO}_{2}$ nanoparticle has proven to be suitable for solution processing. [41] [24] [42] [43] It is therefore a suitable alternative for complete solution processed roll-to-roll OPV comprising printing or slot die coating.

The UV-light absoption of $\mathrm{ZnO}$ is seen in Figure 3 together with the optical transmittance spectra of our slot die coated $\mathrm{ZnO}$ and $\mathrm{SnO}_{2}$ on PET substrate. At $380 \mathrm{~nm}$, the transmittance drops to $50 \%$ in $\mathrm{ZnO}$ whereas the decrease in transmittance of $\mathrm{SnO}_{2}$ is at $330 \mathrm{~nm}$. Both $\mathrm{SnO}_{2}$ and $\mathrm{ZnO}$ nanoparticle layers have a good transmittance around $90 \%$ between $500-800 \mathrm{~nm}$. This is an ideal range to harvest indoor light from FL and LED that have most of the light intensity in the same region (see Figure 2). In addition, the absorption spectra of PV2001:PCBM blend shown in Figure 4 has a broad absorption between 530 - $750 \mathrm{~nm}$, thus has a good spectral overlap with that of the FL and LED. 
Indoor light requires an active material with high open-circuit voltage $\left(V_{O C}\right)$ in 1 sun. $V_{\text {OC }}$ has a logarithmic dependence on the photocurrent density, which in turn is approximately linearly proportional to the incident light intensity. [1] [16] As the light intensity decreases under indoor lighting OPV devices with high $\mathrm{V}_{\mathrm{OC}}$ under 1 sun are expected to have a fairly good $\mathrm{V}_{\mathrm{OC}}$ also in indoor applications. The enhancement of photocurrent in OPV devices under indoor lighting is closely related to the maximum light absorption and minimum leakage current. [17] To minimise the leakage current trough pinholes and to allow more photons to be absorbed, a thicker active layer is more suitable for indoor systems in comparison to an outdoor system at 1 sun. [15] As a result, the OPVs produced in this study for indoor lighting have a comparatively thick photoactive layer (PAL) (600 nm in cells and $800 \mathrm{~nm}$ in modules) and exhibit high $\mathrm{V}_{\mathrm{OC}}$ under 1 sun condition. Both the cells and modules with the active blend of PV2001:PCBM give an average $\mathrm{V}_{O C}$ of $0.75 \mathrm{~V} /$ cell in 1 sun regardles which ETL material was used (see Table 2).

\section{Illumination under 1sun and indoor light}

Before comparing the OPV performance under low light, the performance under 1 sun condition was first studied and the results are shown in Table 2. In AM1.5 measurements, the $\mathrm{ZnO}$ with a grid structure in top electrode ( $\mathrm{ZnO} / \mathrm{grid})$ had the highest average PCE of 4,4\% in cells. This resulted in slightly higher current in comparison to $\mathrm{SnO}_{2} /$ grid containing cells, which had an average PCE of $3.9 \%$. Consequently, the maximum output power $\left(\mathrm{P}_{\mathrm{mpp}}\right)$ of $\mathrm{ZnO} /$ grid cells was the highest, providing 1.5 $\mathrm{mW}$ whereas $1.3 \mathrm{~mW}$ was obtained with $\mathrm{SnO}_{2} /$ grid. Since there was no significant difference in AM1.5 measurement between the top electrode patterns (full coverage vs. grid), 1 sun measurements were conducted for module comprising 8 serially connected cells with grid structure in top silver electrode, see. The encapsulated modules generated PCE of $4.6 \%$ and $3.4 \%$ for $\mathrm{ZnO}$ and $\mathrm{SnO}_{2}$ containing devices, respectively. In upscaling of OPV cells to modules the performance remained nearly the same. Only the average current density per cell $\left(\mathrm{J}_{\mathrm{SC}} / \mathrm{cell}\right)$ increased for $\mathrm{ZnO}$ modules from 11.87 to $14.35 \mathrm{~mA} / \mathrm{cm}^{2} \mathrm{and}$ decreased for $\mathrm{SnO}_{2}$ modules from 11.76 to $10.10 \mathrm{~mA} / \mathrm{cm}^{2}$, but $\mathrm{V}_{\mathrm{OC}}$ remained at $0.75 \mathrm{~V} /$ cell and $\mathrm{FF}$ was between $0.4-0.5$. Changes in $\mathrm{J}_{\mathrm{SC}}$ refers to light absortion efficiency (changes in the layer thickness of PAL) and also to fluctuation in interfacial charge transfer efficiency due to delamination, degradation of materials or trap formation, which also affect the FF and serial resistance. [15] [44] The calculated average serial resistance $\left(\mathrm{R}_{\mathrm{S}}\right)$ from the I-V curve of modules under AM1.5 illumination are shown in Table 4. $\mathrm{R}_{\mathrm{S}}$ was $56.6 \Omega$ and $45.9 \Omega$ in $\mathrm{ZnO}$ and $\mathrm{SnO}_{2}$ containing modules, respectively, suggesting that $\mathrm{ZnO}$ modules were inferior to $\mathrm{SnO}_{2}$ modules in terms of charge transport trough PAL/ETL interface.

For indoor lighting measuremets three best working cells in AM1.5. were taken from each group and measured under 200, 400, 800 and 1000 lux for FL and LED. Measuring parameters are listed in Table 3. The difference in photovoltaic behavior between $\mathrm{ZnO}$ and $\mathrm{SnO}_{2}$ devices was more distinct under indoor light conditions where devices containing $\mathrm{SnO}_{2}$ as ETL were performing better than devices with ZnO. PCE in the cells were between 5.6-10.0\% and 11.4-13.5 \%, while PCE in modules were 9.0$10.8 \%$ and 12.3-13.4\% for $\mathrm{ZnO}$ and $\mathrm{SnO}_{2}$ devices, respectively, regardless wether the indoor light source was FL or LED. The diffenrence between $\mathrm{ZnO}$ and $\mathrm{SnO}_{2}$ is more clearly seen in EQE measurement of OPV cells shown in Figure 4 where $\mathrm{SnO}_{2}$ /grid exhibited much higher EQE of $76.2 \%$ than $\mathrm{ZnO} /$ grid cells with EQE of $57.5 \%$. Most likely this is due to the fact that $\mathrm{UV}$-light exposure of $\mathrm{ZnO}$ was needed for device activation process, thereby to decrease the charge extraction barrier of $\mathrm{ZnO}$ layer in AM1.5 measurement. [5] [23] Fluorescent lamp and LED light lack the UV-light portion that is shown as a red circle in AM1.5 spectrum in Figure 2.

In addition to ETL material, grid structure in top electrode resulted in much higher PCE values for cells than for full coverage top electrode. The superiority of the grid structure was more evident in $\mathrm{ZnO}$ cells as compared to $\mathrm{SnO}_{2}$ cells due to the slightly greater $\mathrm{I}_{\mathrm{SC}} / \mathrm{J}_{\mathrm{SC}}$ and $\mathrm{FF}$ values of $\mathrm{ZnO} /$ grid devices in comparison to $\mathrm{ZnO} /$ full. A significant enhancement of $\mathrm{FF}$ from $\mathrm{AM} 1.5$ measurements was observed especially in $\mathrm{SnO}_{2}$ /grid cells showing an increment from $44 \%$ up to $67 \%$ under FL/LED, which is an indication of good charge transfer between PAL and ETL/HTL. [44] As a result, the highest PCE of $13.5 \%$ in cells was obtained from $\mathrm{SnO}_{2} /$ grid under 400 and 800 lux FL.

The current values $\mathrm{I}_{\mathrm{SC}} / \mathrm{J}_{\mathrm{SC}}$ and $\mathrm{P}_{\max }$ parameteres under the LED light were sligtly higher than under FL as the input power intensity was higer for LED than FL at each illuminance value. However, this was taken into account in PCE and the difference evened out mostly and at some illuminance the FL gave higher PCE than LED. The $\mathrm{I}_{\mathrm{SC}} / \mathrm{J}_{\mathrm{SC}}$ increased along with the illuminance level as well as $\mathrm{V}_{\mathrm{OC}}$, and at 1000 lux the $\mathrm{V}_{\mathrm{OC}}$ reached the level of $0.6 \mathrm{~V}$ in each cell type. A similar kind of trend in $\mathrm{I}_{\mathrm{SC}}, \mathrm{J}_{\mathrm{SC}}$, $\mathrm{P}_{\max }, \mathrm{V}_{\mathrm{OC}}$ and PCE as a function of illuminance and light source type was obtained for the modules. Under 200,800 and 1000 lux FL, the $\mathrm{SnO}_{2}$ /grid modules showed an average PCE of $13.4 \%$, which was the highest PCE obtained from modules in this study under indoor lighting. This is the highest reported indoor efficiency for R2R upscaled, fully solution processed modules 
prepared on flexible substrate. In 1 sun illumination a series resistance is the limiting factor to the performance of OPV especially for the $\mathrm{FF}$ and $\mathrm{J}_{\mathrm{SC}}$, whereas low light intensity requires a high shunt resistance $\left(\mathrm{R}_{\mathrm{SH}}\right)$ to prevent leakage current in the device since the photoinduces current density is low. [17] [45] The averege $\mathrm{R}_{\mathrm{SH}}$ was more than 1.5 times greater in $\mathrm{SnO}_{2}$ than $\mathrm{ZnO}$ modules. Table 4 validates the excellence of $\mathrm{SnO}_{2}$ as ETL in OPV devices expanded to indoor light.

\section{Conclusions}

The performance of a fully solution processed inverted OPV devices on a flexible substrate under 1 sun as well as under different indoor light sources and illuminance conditions was studied. A comparison between two electron transport materials $\mathrm{ZnO}$ and $\mathrm{SnO}_{2}$ and two back electrode pattern was made. The transmittance of electron transport layers and spectral overlap between the spectra of the different indoor light sources, as well as the absorption of PV2000 donor polymer was a good match for producing relativlely high efficient devices under fluorescent lamp and LED illumination. At a certain lux level, LED has a higher irradiance $\left(\mathrm{mW} / \mathrm{cm}^{2}\right)$ than a FL, and that was observed as an increment in current values. The increased current values was also observed in grid structured top electrode cells from fully covered alongside to slightly increased $V_{O C}$ and FF. The encapsulated $\mathrm{SnO}_{2}$ containing samples with grid structured top electrode demonstrated high indoor light harvesting properties with power conversion efficiency up to $13.5 \%$ in cells and $13.4 \%$ in modules. The devices exhibit a stable PCE from cells to modules under indoor light both in $\mathrm{ZnO}$ and $\mathrm{SnO}_{2}$ containing devices. The good performance of light soaking free $\mathrm{SnO}_{2}$ nanoparticle ink was shown to be an alternative material for $\mathrm{ZnO}$ nanoparticle ink when used as an electron transport material in solution processed OPV devices for indoor applications.

\section{Acknowledgements}

The authors acknowledge financial support from Eni S.p.A and VTT Technical Reseach Centre of Finland Ltd. Part of the facilities used were provided by the Academy of Finland Research Infrastructure "Printed Intelligence Infrastructure (PII-FIRI, grant no. 320020). The work is part of the Academy of Finland Flagship Programme, Photonics Research and Innovation (PREIN), decision 320168. Minna Kehusmaa is acknowledged for assisting in the characterization of the devices, Hannu Sääskilahti and Pekka Ontero for operating R2R machines, Riikka Hedman for operating S2S screen printing machine, Pentti Korhonen for drawing the layouts and ordering the slot die shims and printing screens, Antti Veijola for photographs and Kofi Brobbey for grammar check.

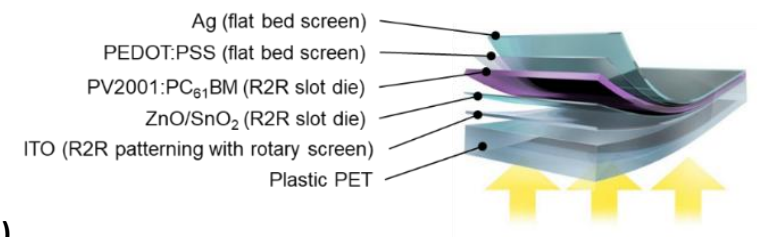

(a) 


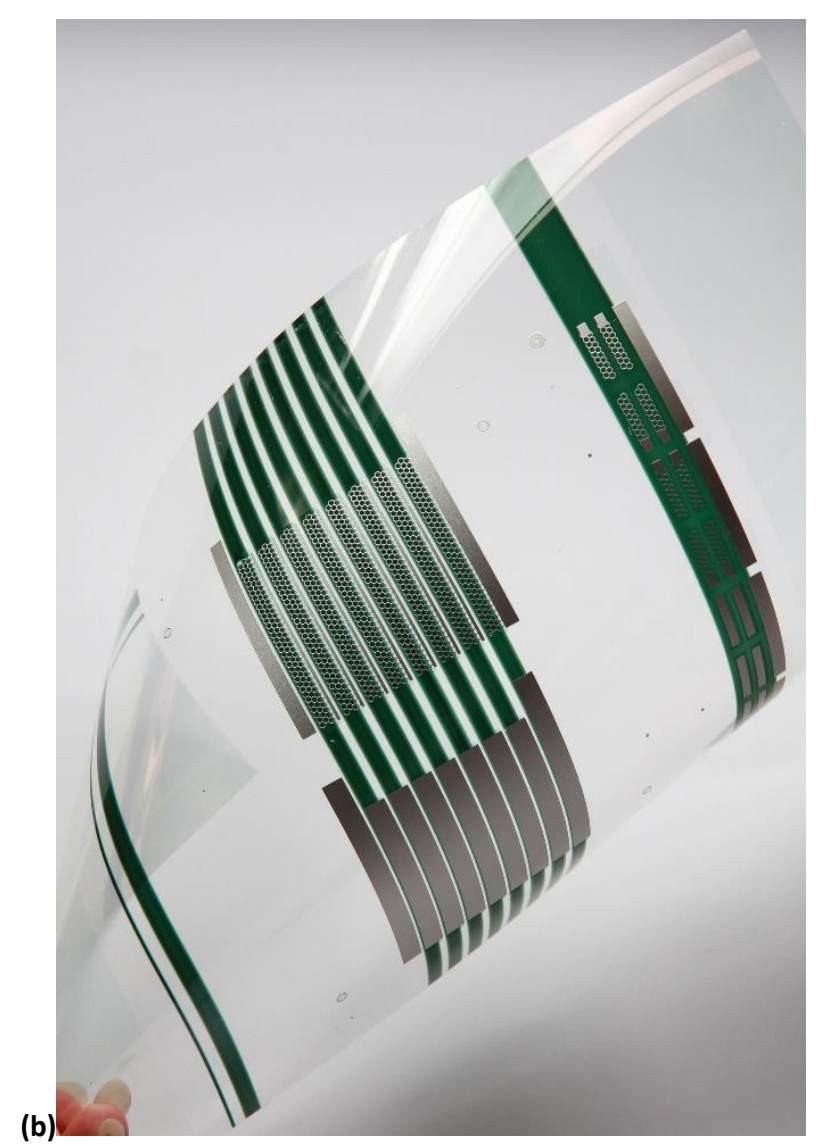

Figure 1 (a) Schematic representation of the OPV devices and (b) photograph of modules and cells in this study

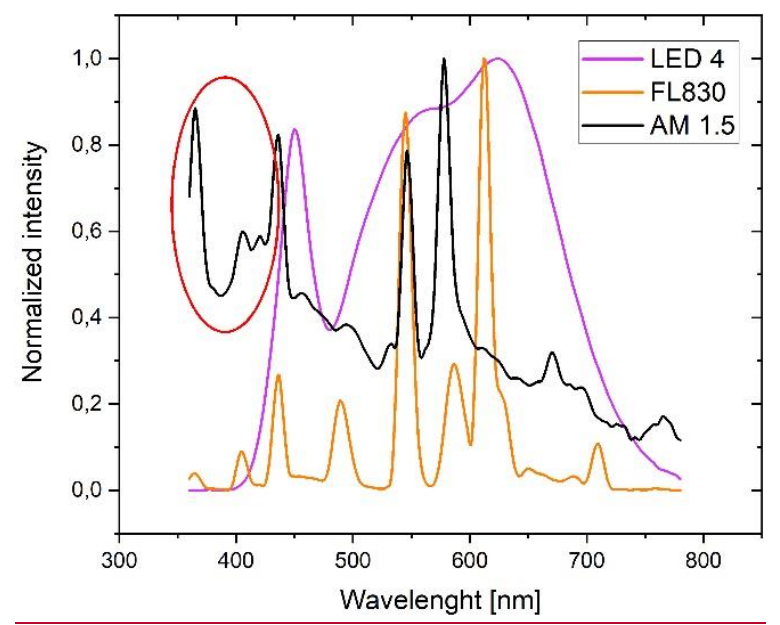

Figure 2 Normalised emission spectrums of AM1.5 solar simulator and indoor light sources at 1000 lux. 


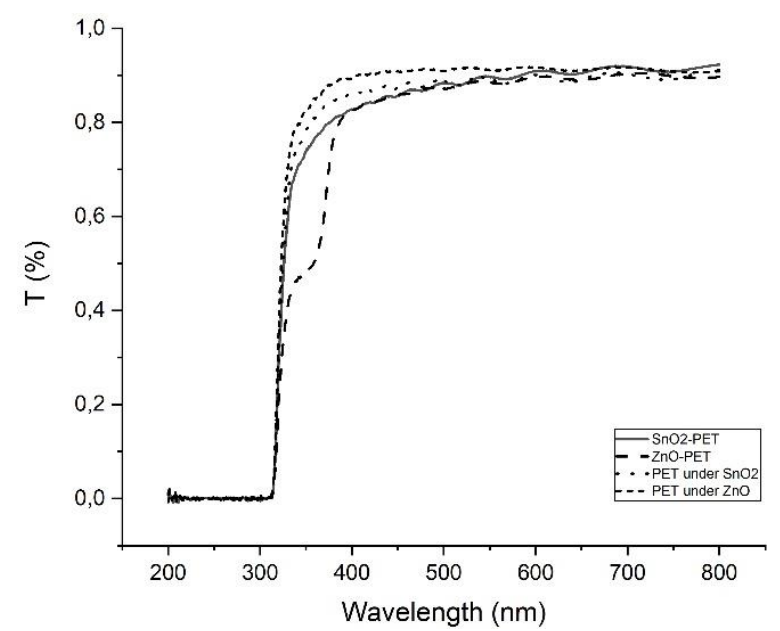

Figure 3 UV-VIS transmittance spectra of PET, PET/SnO2 and PET/ZnO

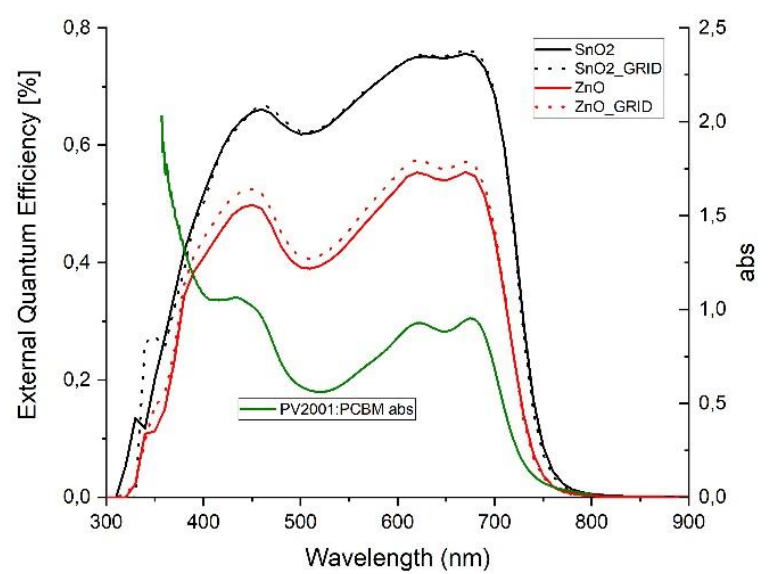

Figure 4 EQE of PV2001 with ZnO and SnO2 as ETL (with a filled (solid line) and grid (dotted line) back contact) and absorption spectra of PV2001.

Table 1 Light intensities of indoor light sources.

\begin{tabular}{ccccc}
\hline $\mathbf{m W} / \mathbf{c m}^{2}$ & 200 lux & 400 lux & 800 lux & 1000 lux \\
\hline FL830 & 0.05662 & 0.11167 & 0.22545 & 0.28452 \\
LED & 0.07120 & 0.14230 & 0.28471 & 0.35660 \\
\hline
\end{tabular}

Table 2 Summary of photovoltaic characteristics of the PV2001:PCBM cells and modules under AM1.5. ${ }^{a}$

\begin{tabular}{|c|c|c|c|c|c|c|c|}
\hline ETL & Ag & $\begin{array}{l}\text { Mean Isc } \\
{[\mathrm{mA}]}\end{array}$ & $\begin{array}{l}\text { Mean } \\
\text { Jsc/cell } \\
{\left[\mathrm{mA} / \mathrm{cm}^{2}\right]} \\
\end{array}$ & $\begin{array}{l}\text { Mean Voc } \\
{[\mathrm{V}]}\end{array}$ & $\begin{array}{l}\text { Mean } P_{\max } \\
{[\mathrm{mW}]}\end{array}$ & $\begin{array}{l}\text { Mean FF } \\
{[\%]}\end{array}$ & $\begin{array}{l}\text { Mean PCE } \\
{[\%]}\end{array}$ \\
\hline \multirow[t]{2}{*}{$\mathrm{ZnO}$} & Full & $3.24 \pm 0.5$ & $9.83 \pm 1.6$ & $0.75 \pm 0.0$ & $1.13 \pm 0.3$ & $46 \pm 3$ & $3.4 \pm 0.8$ \\
\hline & Grid & $3.92 \pm 0.3$ & $11.87 \pm 1.0$ & $0.75 \pm 0.0$ & $1.45 \pm 0.2$ & $49 \pm 3$ & $4.4 \pm 0.6$ \\
\hline \multirow{2}{*}{$\mathrm{SnO}_{2}$} & Full & $3.74 \pm 0.4$ & $11.34 \pm 1.3$ & $0.75 \pm 0.0$ & $1.20 \pm 0.1$ & $43 \pm 2$ & $3.6 \pm 0.4$ \\
\hline & Grid & $3.88 \pm 0.4$ & $11.76 \pm 1.2$ & $0.75 \pm 0.0$ & $1.28 \pm 0.1$ & $44 \pm 1$ & $3.9 \pm 0.4$ \\
\hline ZnO Module & Grid & 24.40 & 14.35 & 5.97 & 62.41 & 43 & 4.6 \\
\hline $\mathrm{SnO}_{2}$ Module & Grid & 17.16 & 10.10 & 5.96 & 46.34 & 45 & 3.4 \\
\hline
\end{tabular}

${ }^{\text {a }}$ The average was calculated from mesurements for 16 cells and 3 modules. 
Table 3 Summary of photovoltaic characteristics of the PV2001:PCBM cells and modules under indoor light sources. ${ }^{a}$

\begin{tabular}{|c|c|c|c|c|c|c|c|c|c|}
\hline ETL & Ag & $\begin{array}{l}\text { light } \\
\text { source }\end{array}$ & $\operatorname{lux}$ & $\begin{array}{l}\text { Mean Isc } \\
{[\mu \mathbf{A}]}\end{array}$ & $\begin{array}{l}\text { Mean } \\
\mathrm{J}_{\mathrm{sc}} / \text { cell } \\
{\left[\boldsymbol{\mu A} / \mathbf{c m}^{2}\right]} \\
\end{array}$ & $\begin{array}{l}\text { Mean Voc } \\
{[\mathrm{V}]}\end{array}$ & $\begin{array}{l}\text { Mean } P_{\max } \\
{[\mu W]}\end{array}$ & $\begin{array}{l}\text { Mean FF } \\
{[\%]}\end{array}$ & $\begin{array}{l}\text { Mean } \\
\text { PCE [\%] }\end{array}$ \\
\hline \multirow[t]{16}{*}{$\mathrm{ZnO}$} & \multirow[t]{4}{*}{ Full } & \multirow[t]{4}{*}{ FL830 } & 200 & 4 & 13.2 & 0.53 & 1.3 & 56 & 6.9 \\
\hline & & & 400 & 9 & 25.9 & 0.56 & 2.4 & 51 & 6.6 \\
\hline & & & 800 & 17 & 52.7 & 0.60 & 5.6 & 54 & 7.5 \\
\hline & & & 1000 & 22 & 66.0 & 0.60 & 7.7 & 58 & 8.2 \\
\hline & \multirow[t]{4}{*}{ Grid } & & 200 & 5 & 15.3 & 0.56 & 1.7 & 60 & 9.0 \\
\hline & & & 400 & 10 & 30.9 & 0.58 & 3.6 & 61 & 9.7 \\
\hline & & & 800 & 20 & 60.7 & 0.60 & 7.4 & 61 & 10.0 \\
\hline & & & 1000 & 25 & 73.6 & 0.61 & 9.3 & 62 & 9.9 \\
\hline & \multirow[t]{4}{*}{ Full } & \multirow[t]{4}{*}{ LED } & 200 & 6 & 17.6 & 0.55 & 1.8 & 56 & 7.5 \\
\hline & & & 400 & 10 & 29.8 & 0.57 & 2.7 & 47 & 5.6 \\
\hline & & & 800 & 20 & 60.2 & 0.60 & 6.3 & 52 & 6.7 \\
\hline & & & 1000 & 25 & 77.8 & 0.61 & 8.5 & 55 & 7.2 \\
\hline & \multirow[t]{4}{*}{ Grid } & & 200 & 7 & 20.2 & 0.56 & 2.3 & 61 & 9.7 \\
\hline & & & 400 & 12 & 36.9 & 0.59 & 4.2 & 59 & 9.0 \\
\hline & & & 800 & 23 & 69.5 & 0.61 & 8.6 & 61 & 9.1 \\
\hline & & & 1000 & 30 & 89.9 & 0.62 & 11.5 & 63 & 9.7 \\
\hline \multirow[t]{16}{*}{$\mathrm{SnO}_{2}$} & \multirow[t]{4}{*}{ Full } & \multirow[t]{4}{*}{ FL830 } & 200 & 6 & 18.2 & 0.54 & 2.1 & 65 & 11.4 \\
\hline & & & 400 & 12 & 37.8 & 0.57 & 4.7 & 66 & 12.7 \\
\hline & & & 800 & 24 & 74.5 & 0.60 & 9.3 & 63 & 12.5 \\
\hline & & & 1000 & 29 & 89.4 & 0.61 & 11.7 & 65 & 12.5 \\
\hline & \multirow[t]{4}{*}{ Grid } & & 200 & 6 & 19.4 & 0.54 & 2.3 & 66 & 12.3 \\
\hline & & & 400 & 13 & 39.6 & 0.57 & 5.0 & 67 & 13.5 \\
\hline & & & 800 & 26 & 77.6 & 0.60 & 10.0 & 65 & 13.5 \\
\hline & & & 1000 & 31 & 92.9 & 0.61 & 12.2 & 66 & 12.9 \\
\hline & \multirow[t]{4}{*}{ Full } & \multirow[t]{4}{*}{ LED } & 200 & 8 & 24.0 & 0.55 & 2.9 & 66 & 12.3 \\
\hline & & & 400 & 15 & 45.5 & 0.57 & 5.6 & 64 & 11.8 \\
\hline & & & 800 & 28 & 86.4 & 0.60 & 10.7 & 62 & 11.4 \\
\hline & & & 1000 & 37 & 111.0 & 0.61 & 13.9 & 62 & 11.8 \\
\hline & \multirow[t]{4}{*}{ Grid } & & 200 & 8 & 24.7 & 0.56 & 3.0 & 67 & 12.9 \\
\hline & & & 400 & 15 & 46.7 & 0.58 & 5.9 & 67 & 12.6 \\
\hline & & & 800 & 29 & 88.2 & 0.60 & 11.5 & 65 & 12.2 \\
\hline & & & 1000 & 37 & 112.8 & 0.61 & 15.0 & 66 & 12.7 \\
\hline \multirow{8}{*}{$\begin{array}{l}\text { ZnO } \\
\text { Mod. }\end{array}$} & \multirow[t]{8}{*}{ Grid } & \multirow[t]{4}{*}{ FL830 } & 200 & 30 & 17.6 & 4.20 & 69.2 & 54 & 9.0 \\
\hline & & & 400 & 59 & 35.2 & 4.49 & 150.5 & 57 & 9.9 \\
\hline & & & 800 & 117 & 68.8 & 4.72 & 322.4 & 58 & 10.5 \\
\hline & & & 1000 & 147 & 86.4 & 4.80 & 412.4 & 58 & 10.8 \\
\hline & & \multirow[t]{4}{*}{ LED } & 200 & 37 & 21.6 & 4.32 & 87.8 & 56 & 9.1 \\
\hline & & & 400 & 73 & 43.2 & 4.52 & 192.3 & 58 & 9.9 \\
\hline & & & 800 & 137 & 80.8 & 4.82 & 383.1 & 58 & 9.9 \\
\hline & & & 1000 & 181 & 106.4 & 4.90 & 514.4 & 58 & 10.7 \\
\hline \multirow{8}{*}{$\begin{array}{l}\mathrm{SnO}_{2} \\
\text { Mod. }\end{array}$} & \multirow[t]{8}{*}{ Grid } & FL830 & 200 & 38 & 22.4 & 4.33 & 102.8 & 62 & 13.4 \\
\hline & & & 400 & 72 & 42.4 & 4.54 & 200.9 & 62 & 13.2 \\
\hline & & & 800 & 142 & 84.0 & 4.74 & 409.6 & 61 & 13.4 \\
\hline & & & 1000 & 177 & 104.0 & 4.81 & 513.2 & 60 & 13.4 \\
\hline & & LED & 200 & 44 & 25.6 & 4.40 & 119.0 & 62 & 12.3 \\
\hline & & & 400 & 87 & 51.2 & 4.62 & 247.1 & 61 & 12.8 \\
\hline & & & 800 & 167 & 98.4 & 4.81 & 490.2 & 61 & 12.7 \\
\hline & & & 1000 & 211 & 124.0 & 4.89 & 628.3 & 61 & 13.0 \\
\hline
\end{tabular}

${ }^{\text {a }}$ The average was calculated from mesurements for 3 cells and 3 modules. 


\begin{tabular}{|c|c|c|c|c|c|}
\hline ETL & $\mathbf{A g}$ & $\begin{array}{l}\text { light } \\
\text { source }\end{array}$ & lux & $\mathbf{R s}[\Omega]$ & $\mathbf{R}_{\mathrm{SH}}[\mathrm{k} \Omega]$ \\
\hline \multirow[t]{9}{*}{$\mathbf{Z n O}$} & Grid & AM1.5 & & 56.6 & 1.16 \\
\hline & & FL830 & 200 & 172.5 & 657 \\
\hline & & & 400 & 171.9 & 401 \\
\hline & & & 800 & 164.6 & 231 \\
\hline & & & 1000 & 182.8 & 188 \\
\hline & & LED & 200 & $\begin{array}{l}194.4 \\
\end{array}$ & 596 \\
\hline & & & 400 & 186.3 & 340 \\
\hline & & & 800 & 188.6 & 196 \\
\hline & & & 1000 & 187.0 & 152 \\
\hline \multirow[t]{9}{*}{$\mathrm{SnO}_{2}$} & Grid & AM1.5 & & 45.9 & 1.00 \\
\hline & & FL830 & 200 & 79.7 & 1326 \\
\hline & & & 400 & 79.6 & 721 \\
\hline & & & 800 & 79.0 & 357 \\
\hline & & & 1000 & 81.5 & 290 \\
\hline & & LED & 200 & 80.1 & 1140 \\
\hline & & & 400 & 81.4 & 589 \\
\hline & & & 800 & 81.2 & 336 \\
\hline & & & 1000 & 80.2 & 295 \\
\hline
\end{tabular}

\section{References}

[1] R. Arai, S. Furukawa, Y. Hidaka, H. Komiyama and T. Yasuda, ACS Appl. Mater. Interfaces, vol. 11, p. 9259, 2019.

[2] H. K. H. Lee, J. Wu, J. Barbé, S. M. Jain, S. Wood, E. M. Speller, Z. Li, F. A. Castro, J. R. Durrant and W. C. Tsoi, J. Mater. Chem. A, vol. 6, p. 5618, 2018.

[3] A. E. Ostfeld and A. C. Arias, Flex. Print. Electron., vol. 013001, p. 2, 2017.

[4] R. R. Søndergaard, M. Hösel and F. C. Krebs, J. Polym. Sci. Part B: Polym. Phys. , vol. 51, p. 16, 2013.

[5] M. Vilkman, K.-L. Väisänen, P. Apilo, R. Po, M. Välimäki, M. Ylikunnari, A. Bernardi, T. Pernu, G. Corso, J. Seitsonen, S. Heinilehto, J. Ruokolainen and J. Hast, ACS Appl. Energy Mater., vol. 1, p. 5977, 2018.

[6] L. Meng, Y. Zhang, X. Wan, C. Li, X. Zhang, Y. Wang, X. Ke, Z. Xiao, L. Ding, R. Xia, H.-L. Yip, Y. Cao and Y. Chen, Science, vol. 361, p. 1094, 2018.

[7] NREL, "Best Research-Cell Efficiency Chart," The National Renewable Energy Laboratory , 26112019. [Online]. Available: nrel.gov/pv/cell-efficiency.html.

[8] R. Yu, H. Yao, Y. Cui, L. Hong, C. He and J. Hou, Adv. Mater., vol. 31, p. 1902302, 2019.

[9] T. Yan, J. Ge, T. Lei, W. Zhang, W. Song, F. Billy, D. Zhang, S. Chen, R. Peng and Z. Ge, J. Mater. Chem. A, vol. 7, p. 25894, 2019.

[10] Y. Cui, Y. Wang, J. Bergqvist, H. Yao, Y. Xu, B. Gao, C. Yang, S. Zhang, O. Inganäs, F. Gao and J. Hou, Nature Energy, vol. 4, p. 768, 2019. 
[11] H. Yin, S. Chen, S. H. Cheung, H. W. Li, Y. Xie, S. W. Tsang, X. Zhu and S. K. So, J. Mater. Chem. C, vol. 6, p. 9111, 2018.

[12] J. S. Goo, S.-C. Shin, Y.-J. You and J. W. Shim, Solar Energy Mater. Solar Cells, vol. 184, p. 31, 2018.

[13] S. Mori, T. Gotanda, Y. Nakano, M. Saito, K. Todori and M. Hosoya, Jpn. J. Appl. Phys., vol. 54, p. 071602, 2015.

[14] P. Vincent, S.-C. Shin, J. S. Goo, Y.-J. You, B. Cho, S. Lee, D.-W. Lee, S. R. Kwon, K.-B. Chung, J.-J. Lee, J.-H. Bae, J. W. Shim and H. Kim, Dyes and Pigments, vol. 159, p. 306, 2018.

[15] S.-C. Shin, C. W. Koh, P. Vincent, J. S. Goo, J.-H. Bae, J.-J. Lee, C. Shin, H. Kim, H. Y. Woo and J. W. Shim, Nano Energy, vol. 58, p. 466, 2019.

[16] H. K. H. Lee, Z. Li, J. R. Durrant and W. C. Tsoi, Appl. Phys. Lett., vol. 108, p. 253301, 2016.

[17] R. Steim, T. Ameri, P. Schilinsky, C. Waldauf, G. Dennler, M. Schaber and C. J. Brabec, Solar Energy Mater. Solar Cells, vol. 95, p. 3256, 2011.

[18] C. L. Cutting, M. Bag and D. Venkataraman, J. Mater. Chem. C, vol. 4, p. 10367, 2016.

[19] Y. Aoki, Organic Electronics, vol. 48, p. 194, 2017.

[20] P. Maisch, K. Tam, L. Lucera, H. Egelhaaf, H. Schreiber, E. Maier and C. Brabec, Organic Electronics, vol. 38, p. 139, 2016.

[21] T. Eggenhuisen, Y. Galagan, A. Biezemans, T. Slaats, W. Voorthuijzen, S. Kommeren, S. Shanmugam, J. Teunissen, A. Hadipour, W. Verhees, S. Veenstra, M. Coenen, J. Gilot, R. Andriessen and W. Groen, J. Mater. Chem. A, vol. 3, no. 14, p. 7255, 2015.

[22] M. List, T. Sarkar, P. Perkhun, J. Ackermann, C. Luo and U. Würfel, Nature Communications, vol. 9, p. 3631, 2018.

[23] Y.-M. Chang, C.-Y. Liao, C.-C. Lee, S.-Y. Lin, N.-W. Teng and P. H.-S. Tan, Solar Energy Mater. Solar Cells, vol. 202, p. 11064, 2019.

[24] S. Trost, A. Behrendt, T. Becker, A. Polywka, P. Görrn and T. Riedl, Adv. Energy Mater., vol. 5, p. 1500277, 2015.

[25] G. A. dos Reis Benatto, M. Corazza, B. Roth, F. Schütte, M. Rengenstein, S. A. Gevorgyan and F. C. Krebs, Energy Technol., vol. 5, p. 338, 2017.

[26] N. H. Reich, W. G. J. H. M. van Sark and W. C. Turkenburg, Renewable Energy, vol. 36, p. 642, 2011.

[27] M. O. Reese, S. A. Gevorgyan, M. Jorgensen, E. Bundgaard, S. R. Kurtz, D. S. Ginley, D. C. Olson, M. T. Lloyd, P. Morvillo, E. A. Katz, A. Elschner, O. Haillant, T. R. Currier, V. Shrotriya, M. Hermenau, M. Riede, K. R. Kirov, G. Trimmel, T. Rath, O. Inganäs, F. Zhang, M. Andersson, K. Tvingstedt, M. Lira-Cantu, D. Laird, C. McGuiness, S. Gowrisanker, M. Pannone, M. Xiao, J. Hauch, R. Steim, D. M. DeLongchamp, R. Rösch, H. 
Hoppe, N. Espinosa, A. Urbina, G. Yaman-Uzunoglu, J.-B. Bonekamp, A. J. van Breemen, C. Girotto, E. Voroshazi and F. C. Krebs, Solar Energy Mater. Solar Cells, vol. 95, p. 1253, 2011.

[28] C. Waldauf, M. Morana, P. Denk, P. Schilinsky, K. Coakley, S. A. Choulis and C. J. Brabec, Appl. Phys. Lett., vol. 89, p. 233517, 2006.

[29] J. Hu, Z. Wu, H. Wei, T. Song and B. Sun, Organic Electronics, vol. 13, p. 1171, 2012.

[30] K. Zilberberg, J. Meyer and T. Riedl, J. Mater. Chem., vol. 1, p. 4796, 2013.

[31] Z. Jiang, S. Soltanian, B. Gholamkhass, A. Aljaafari and P. Servati, RSC Adv., vol. 8, p. 36542, 2018.

[32] S. Huang, Y. Tang, A. Yu, Y. Wang, S. Shen, B. Kang, S. R. P. Silva and G. Lu, Org. Electronics, vol. 62, p. 373, 2018.

[33] Z. Yang, T. Zhang, J. Li, W. Xue, C. Han, Y. Cheng, L. Qian, W. Cao, Y. Yang and S. Chen, Scientific Reports, vol. 7, p. 9571, 2017.

[34] N. Wu, Q. Luo, S. Bao, J. Lin, Y. Li and C. Ma, Solar Energy Mater. Solar Cells, vol. 141, p. 248, 2015.

[35] Y. Jiang, L. Sun, F. Jiang, C. Xie, L. Hu, X. Dong, F. Qin, T. Liu, L. Hu, X. Jiang and Y. Zhou, Mater. Horiz., vol. 6, p. 1438, 2019.

[36] J. Kim, G. Kim, Y. Choi, J. Lee, S. Heum Park and K. Lee, J. Appl. Phys., vol. 111, p. 114511, 2012.

[37] W. Ke, G. Fang, Q. Liu, L. Xiong, P. Qin, H. Tao, J. Wang, H. Lei, B. Li, J. Wan, G. Yang and Y. Yan, J. Am. Chem. Soc., vol. 137, p. 6730, 2015.

[38] E. H. Anaraki, A. Kermanpur, L. Steier, K. Domanski, T. Matsui, W. Tress, M. Saliba, A. Abate, M. Grätzel, A. Hagfeldt and J.-P. Correa-Baena, Energy Environ. Sci., vol. 9, p. 3128, 2016.

[39] Z. Zhu, Y. Bai, X. Liu, C.-C. Chueh, S. Yang and A. K.-Y. Jen, Adv. Mater., vol. 28, p. 6478, 2016.

[40] Q. Jiang, L. Zhang, H. Wang, X. Yang, J. Meng, H. Liu, Z. Yin, J. Wu, X. Zhang and J. You, Nat. Energy, vol. 2, p. 16177, 2016.

[41] B. Bob, T.-S. Song, C.-C. Chen, Z. Xu and Y. Yang, Chem. Mater., vol. 25, p. 4725, 2013.

[42] V.-H. Tran, R. B. Ambade, S. B. Ambade, S.-H. Lee and I.-H. Lee, Appl. Mater. Interfaces, vol. 9, p. 1645, 2017.

[43] T. Bu, J. Li, F. Zheng, W. Chen, X. Wen, Z. Ku, Y. Peng, J. Zhong, Y.-B. Cheng and F. Huang, Nature Commun., vol. 9, p. 4609, 2018.

[44] N. Grossiord, J. M. Kroon, R. Andriessen and P. W. Blom, Org. Electronics, vol. 13, p. 432, 2012.

[45] C. M. Proctor and T.-Q. Nguyen, Appl. Phys. Lett., vol. 106, p. 083301, 2015. 
[46] M. Tavakoli, H. Dastjerdi, J. Zhao, K. Shulenberger, C. Carbonera, R. Po, A. Cominetti, G. Bianchi, N. Klein, M. Bawendi, S. Gradecak and J. Kong, Small, vol. 15, p. 1900508, 2019.

[47] Yrjänä, 2014.

[48] H. Yin, J. K. W. Ho, S. H. Cheung, R. J. Yan, K. L. Chiu, X. Hao and S. K. So, J. Mater. Chem. A, vol. 6, p. 8579, 2018.

[49] Z. Xiao, X. Jia and L. Ding, Science Bulletin, vol. 62, p. 1562, 2017.

[50] J. Hou, O. Inganäs, R. H. Friend and F. Gao, Nature Materials, vol. 17, p. 119, 2018. 